\title{
TEACHING ABOUT SUSTAINABILITY IN A BUSINESS SCHOOL
}

\author{
Robert Girling (CSU)*
}

\begin{abstract}
Education for sustainability is essential in order to develop individuals with knowledge and skills to make decisions based on their environmental, social and economic context with an orientation toward action and change. More and more companies and business leaders around the world realize that they can benefit from a range of sustainable business initiatives which reduce costs or provide strategic advantages. Consequently there is a need for an adult education system to inform students as well as provide training needed to provide solutions by a new generation of company leaders and new demands by governments and international agencies. This article discusses how adult teachers in business schools can combine lectures, multimedia and an experiential simulation to teach about the tools and benefits of sustainable business strategies.
\end{abstract}

Keywords: education for sustainability - adult education - sustainable business strategies.

\section{RESUMO}

\section{ENSINANDO SOBRE SUSTENTABILIDADE EM UMA ESCOLA DE NEGÓCIOS}

Educação para sustentabilidade é essencial fim de preparar individuos com conhecimentos e habilidades para tomarem decisões baseadas no meio ambiente e no contexto social e economico com orientação para ação e mudanças. Mais e mais companhias e lideres empresariais ao redor do mundo entendem que podem se beneficiar de um larga lista de iniciativas de negócios sustentáveis que reduzem custos e desenvolvem estratégias vantajosas. Consequentemente, há necessidade de um sistema de educação para jovens e adultos para que tenham acesso às informações e sejam treinados com o objetivo de buscar soluções para a nova geração de lideres empresarias , assim como para as novas demandas dos governos e de agências internacionais. Este artigo discute como professores de adultos em escolas de negocios combinam leituras, multimedia e experiências de simulação para ensinar as ferramentas e beneficios de negocios sustentáveis.

Palavras chave: educação para sustentabilidade- educação de adultos- estratégias de negócio sustentável.

* Ph. D. em Educação; Professor Emeritus; School of Business and Economics. Sonoma State University; California State University. E-mail: girling@sonuma.edu 


\section{RESUMEN \\ ENSEÑANZA SOBRE SOSTENIBILIDADEN UNA ESCUELA DE NEGOCIOS}

La educación para la sostenibilidad es esencial para desarrollar individuos con conocimientos y habilidades para tomar decisiones basadas en su contexto ambiental, social y económico con una orientación hacia la acción y el cambio. Cada vez más empresas y líderes empresariales de todo el mundo se dan cuenta de que pueden beneficiarse de una serie de iniciativas empresariales sostenibles que reducen los costos o proporcionan ventajas estratégicas. En consecuencia, existe la necesidad de un sistema de educación de adultos para informar a los estudiantes, así como proporcionar la capacitación necesaria para proporcionar soluciones por parte de una nueva generación de líderes de empresas y nuevas demandas de los gobiernos y agencias internacionales. En este artículo se explica cómo los maestros de adultos en las universidades pueden combinar conferencias, multimedia y una simulación experiencial para enseñar sobre las herramientas y los beneficios de las estrategias de negocios sostenibles.

Palavras clave: la educaccio para la sostenibilidad, educacion para adultos, las estratgias de negocios sostenibles

\section{INTRODUCTION}

Each passing week brings our attention to the growing list of environmental issues facing our planet. From melting glaciers, to natural disasters like the Hurricanes Maria and Katrina we are awakening to the impact of our system of production and consumption on our environment. Companies around the world have been spurred to action by the Report of the International Panel on Climate Change, by a tightening regulatory environment in the European Union and in California as well as changing consumer priorities. Moreover, corporate leadership organizations such as Instituto Ethos in Brazil and Business for Social Responsibility in the US are working to promote and assist businesses to develop strategies for achieving social and environmental justice.

There is a sea change in the business environment that mirrors the growing environmental awareness in our society. Graduates need to be prepared to deal with the array of environmental as well as social risks and regulations and they need to be informed about the nature of sustainability as it pertains to business and society. The question that faces adult educators including professors and teachers of business is how best to bring this information into the classroom so that our curriculum reflects the changing reality while effectively preparing the next generation of managers, entrepreneurs and societal leaders. And it is equally as important that they have a clear understanding of the tools that they can use to make business sustainable, such that business moves from being part of the problem to a vital part of the solution.

A growing number of companies have shifted their focus toward triple-bottom-line, environmentally sound solutions. For example, insurance companies, who have to pick up the tab for environmental disasters such as Hurricane Maria and the 
California wildfires have moved to the forefront of those demanding sustainable solutions. The costs of ignoring sustainability principles can be high. City attorneys from Oakland and San Francisco are suing five of the largest oil and gas companies, alleging they knowingly contributed to global warming by producing and promoting the use of fossil fuels. The Oakland attorneys are seeking payment in the form of an abatement fund from the oil companies that would go towards building infrastructures that would protect residents from the effects of global warming. ${ }^{1}$

Emerging trends around the world and particularly within the European Community are setting new standards with respect to product design, waste treatment, and a host of other operational issues that most businesses will need to consider in developing their strategies. In order to respond to the changing regulatory environment, are changing their business strategies.

As Jonathan Lash and Fred Wellington of the World Resources Institute point out "Companies that manage and mitigate their exposure to climate-change risks while seeing new opportunities for profit will generate competitive advantage over rivals in a carbon-constrained future." (Lash and Wellington, 2007, p. 96)

General Electric has changed its strategy and is investing heavily to position itself as a leading innovator in a wide range of products from wind power and LED lighting to hybrid engines. Tesla has developed R\&D for electric vehicles, storage batteries as well as roof tiles that deliver solar power to buildings. Even Wal-Mart is moving toward sustainability, through its Project Gigaton

1 https://oaklandnorth.net/2017/09/22/oakland-san-francisco-sue-the-countrys-five-largest-oil-and-gas-companies/ a Walmart initiative announced in 2017 to avoid one billion metric tons (a gigaton) of greenhouse gases from the global value chain by 2030 .

And mutual fund investments in socially and environmentally screened funds

have soared from \$12 billion in 1995 to $\$ 12$ trillion as of year end 2017 according to the US SIF Foundation's 2018 Report on US Sustainable, Responsible and Impact Investing Trends. This means that more than one out of every four dollars under professional management in the United States was invested according to SRI strategies! ${ }^{2}$

The question which arises is how to encourage and educate adult learners in business schools to consider environmental issues. In my teaching, I have found it helpful to begin with definitions and visual images to set the stage and engage the interest of the students followed by a discussion of the meaning of sustainability. The concepts of sustainability, sustainable development and the "triple bottom line" provides a theoretical framework. The concept of sustainability can be somewhat confusing as there are a host of competing definitions. One widely used definition is "Meeting humanity's needs today without harming future generations." A more comprehensive definition is Herman Daly's proposal that (a) rates of use of renewable resources should not exceed their rates of regeneration, (b)rates of use of non-renewable resources should not exceed rate at which renewable substitutes are developed and (c) rates of pollution should not exceed the assimilative capacity of the environment.

It is not unusual for business students to wonder just what all of this has got to do with business. While many business people

\footnotetext{
2 http://www.socialinvest.org/pdf/research/ Trends/2005\%20Trends\%20Report.pdf and https://www.ussif.org/sribasics
} 
may argue that it is their responsibility to make a profit-not save the world-- the fact is that business needs stable markets and healthy consumers and, uniquely, business has the technology, finance and management skills needed to achieve a transition to sustainability.

Many videos and films are now available that illustrate the dimensions of the issues facing the planet. For example, "Surviving Progress" presents the story of human advancement as awe-inspiring and double-edged. It reveals the grave risk of running the 21st century's software - our knowhow - on the ancient hardware of our primate brain which hasn't been upgraded in 50,000 years. "The Eagle and the Condor" prepared by the Pachamama Alliance shows the connection between the global metropolises and the plight of the Amazon rain forest and the Achuar peoples. And former US Vice President Al Gore's documentary "An Inconvenient Truth," provides a comprehensive discussion of climate change replete with statistical data and charts. Visual images get the attention of students who may not have thought much about the environment.

Business school faculty can use a combination of textbooks, lectures and case studies about companies such as Natura Brasil which has established an ethical trade with the communities of Amazonia and the Atlantic forest and contributes in improving the income of more than 2000 families living in communities that preserve 250,000 hectares of forest giving a better future for generations to come.

This allows students to examine how companies have applied the concepts of sustainability in developing their business strategies. Sustainability also provides another avenue for teaching the concepts of corporate social responsibility.

\section{ACCORDING TO A REPORT PREPARED BY A GLOBAL ACCOUNTING FIRM}

Sustainability may sound like yet another corporate buzz word, the latest fad in a long line of management fads. But sustainability is serious business. A new standard of performance that measures the social, environmental, and economic effects of business activities-the so-called "triple bottom line"-it can mean the difference between a company's long term success or failure. Alas, few corporations recognize the links between sustainability, reputation, and financial performance. However, without a sustainability risk management program in place, companies are flirting with disaster. A major misstep or miscalculation on triple-bottom-line issues can ruin reputations, jeopardize corporate financial integrity, and imperil relationships with customers, investors, and the banks....Companies are converging in first generation sustainability themes like corporate governance, and transparency and accountability along the whole supply chain are increasingly visible through policies and control mechanisms. ${ }^{3}$

What are some leading companies are doing with respect to sustainability? I begin my classes by examining approaches by businesses around the world provide. I find it helpful to point to additional factors driving business concerns with the environment. These include the problems of solid waste disposal, adequacy of energy and water supplies and supply chain reliability. Case studies of what some companies are doing is articulated in my book The Good Company: Sustainability in Hospitality, Tourism and the Wine Industries. [Business Expert Press. 2016]

3 Pricewaterhouse Coopers; Integral Business: Integrating sustainability and business strategy." www.pwc.com/sustainability 
The cases help students to gain insights into the strategies which some companies such as Interface are using in order to design products as well as services that produce less waste, use fewer resources and contain more recycled and less toxic components. For example, the European Union's Directive on Waste Electrical and Electronic Equipment requires producers, importers and distributors to arrange take-back and recycling or waste electrical equipment and Dell Computer Corporation has responded by changing its production strategy in its world-wide operations.

Each student is required to prepare a response paper that answers the following questions:

- What is sustainability and what has motivated society to pay attention to sustainability?

- What do you think has led companies to integrate sustainability into their business strategies?

- Identify three or more specific metrics or ways by which a company's performance could be measured with respect to sustainability.

\section{APPLICATION OF THEORY TO PRACTICE}

I also use a business simulation in which students operate a virtual company. CAPSIM is a problem-based learning simulation of a technology company in which teams of students design, produce and market and finance high-tech sensors in competition with each other. It is a vehicle for students who are completing their undergraduate university education or MBA and need to know how all the parts of business fit together.

It is a challenging simulation which engages student participants in designing, planning and executing a strategy. It chal- lenges them to put into practice, not just write about, their knowledge about business that they have learned throughout their college career. They must develop a strategy to restore their floundering company to financial health. Each week they practice applying management skills and building strategies making about 125 specific business decisions ranging from handling inventories to the best ways to market their products. In the simulation students learn

- to weigh the advantages and disadvantages of alternative business strategies;

- the importance of designing products to meet customer needs

- how develop and organize a team and how to provide support for each other

- how to plan and to make business decisions

- how to interpret financial results

- to research and develop an environmental management system (EMS)

As a component to the simulation, each student is required to apply the principles of sustainability to their company by researching current environmental regulations related to business and society on the United Nations Environmental Program and the US Environmental Protection Agency (EPA) web-sites. Using this information they prepare a power point presentation of an Environmental Management System to enable their company to become more sustainable. This power point then becomes incorporated into each team's presentation to a "Board of Directors" comprised of outside experts drawn from the business community.

\section{CONCLUSIONS}

This methodology provides students with an understanding of sustainability which is grounded in the concept of business strat- 
egy. Students see a connection between business and the environment that is based in what specific companies are doing to develop strategies for sustainable production, purchasing and operations. In addition they gain an appreciation for a sustainable vision of corporate social responsibility which

- Focuses on outcomes over future generation;

- Builds upon an integrative approach to meet interdependent goals of social equity, environmental quality and economic viability,

- Emphasizes a systems approach to problem-solving and decision-making, which incorporates full cost accounting in decision-making, including environmental and operating costs;

- Recognizes ecological limits as a fundamental business constraint.

In addition, students become aware of alternative strategies such as elimination of use of hazardous chemicals, redesign of products to make them more durable or easily repairable, the design of life-cycle product that can be recovered and replacement of nonrenewable materials with more sustainable materials.

\section{SOME RESULTS}

Students in the Strategic Management class write about what they have learned and how they might apply their knowledge in their current or future employment as part of their final examination paper. The following is a representative response from an adult learner:

'I currently work for Marmot, a company that makes outdoor recreational apparel and equipment. Being a company whose sole purpose of their products is for outdoor recreation, the issues of sustainability greatly impact the success of the company. Consum- ers, athletes, and employees who buy and use their products extensively in the outdoors demand that what goes into the product has a positive impact on the environment that they cherish. Marmot contracts out all manufacturing overseas in India and China. Marmot must focus on Quality control in order to maintain their standards. Their current Vendor Code of Conduct states:

"Marmot considers workers rights, their well being and their working conditions to be paramount in the selection of all contractors. Marmot chooses to only nominate contractors who exhibit exceptional work environments and outstanding general well being programs such as on-site day care, on-site health care, on-site housing and/or meals and who provide continuing educational programs. In additional Marmot nominated contractors must meet or surpass the national and local labor standards in terms of minimum age, hours of work and work environment"

The company only uses dyes that are organic and vegan. Some outdoor apparel companies use a red dye that contain shell fish or a blue dye that is harsh on the environment and contaminates water. Marmot also only uses fabrics, cotton, and other raw material that were organically produced. The company also focuses on in-house operations. Employees are encouraged to conserve energy and water in the offices. The company even dropped producing catalogs, which they relied heavily on in the past, to eliminate paper waste. Marmot also has employee training programs and community volunteer work. The company is also big on giving back to the local community by participating and donating to local events, charities, and education. Marmot also works exclusively with nonprofit organizations such as the dZi Foundation. The dZi Foundation develops sustainable programs that positively impact individuals and communities located primarily within the Hi- 
malayan region. Their work is focused in the areas of education, health and welfare. These programs are designed to serve within the existing social framework, maintaining particular sensitivity to local culture and tradition. Marmot also works closely with Business for Wilderness which focuses on Wild places provide high quality outdoor recreation destinations."

\section{Karyn Pascal}

\section{REFERENCES}

Christine Arena; (2004) Cause for Success. New World Library.

Pete Engardio, "Beyond the Green Corporation" Business Week January 29, 2007. pp. 50-64.

Gary Erickson. (2004) Raising the Bar: The Story of Clif Bar Inc. Jossey Bass.

Paola Schmitt Figueiró, Bruno Anicet Bittencourt and Soraia Schutel (2016) Education for sustainability in business schools by practicing social learning. Brazilian Journal of Science and Technology [2016 3:11].

Robert Girling, Heather Gordy and Pamela Lainer; (2016) The Good Company: Sustainability in Hospitality, Tourism and the Wine Industries. Business Expert Press, 2016.

Andrew John Hoffman, (2018) The Next Phase of Business Sustainability (January 1, 2018).
Stanford Social Innovation Review, 16(2): 3439.; Ross School of Business Paper No. 1381. Available at SSRN: https://ssrn.com/abstract=3191035 or http://dx.doi.org/10.2139/ ssrn.3191035.

Charles Holliday, Stephan Schmidheiny and Philip Watts, (2002) Walking the Talk: The Business Case for Sustainable Development. Barrett-Koehler.

Jonathan Lash and Fred Wellington, (2007) "Competitive Advantage on a Warming Planet;" Harvard Business Review, March 2007. pp. 95102.

Brian Natrass and Mary Altomare ; (2002) Dancing with the Tiger: Learning Sustainability Step by Natural Step. New Society Publishers.

Pricewaterhouse Coopers; Integral Business: Integrating sustainability and business strategy." www.pwc.com/sustainability.

UNESCO (2006) Water, A Shared Responsibility. United Nations. http://www.socialinvest.org/ pdf/research/Trends/2005\%20Trends\%20Report.pdf.

United States EPA, Smart Steps To Sustainability 2.0. (2017). https://www.epa.gov/sites/production/files/documents/smart_steps_greening_guide.pdf. 